\title{
MUTAGENESIS AND GENETIC TRANSFORMATION OF MEIOTIC SEGREGANTS OF LAGER YEAST
}

by

\author{
CLAES GJERMANSEN
}

Department of Physiology, Carlsberg Laboratory, Gamle Carisberg Vej 10, DK-2500 Copenhagen Valby

Keywords: Brewers yeast, auxotrophic mutants, transformation

Auxotrophic mutants have been induced by UV-irradiation or EMS treatment in meiotic segregants of the Carlsberg lager production strain. In complementation tests some of the mutations were allelic to adel, ade2, adeb, hisl, leu2, lys5 and ura2 of S. cerevisiae.

A leu2 mutant was transformed to leucine prototrophy by pYF91.2, a self-replicating plasmid containing $L E U 2$ from S. cerevisiae. The transformants are unstable for the Leu $\mathrm{L}^{+}$phenotype on non-selective medium and DNA hybridization analysis of one of the transformants, using a radioactively labeled probe, showed the presence of plasmid sequences in the transformant.

\section{INTRODUCTION}

A comprehensive knowledge of the genetics of laboratory strains of Saccharomyces cerevisiae has been accumulated since the discovery of its sexual reproduction. In contrast, genetical characterization of industrial yeasts has been impeded by their poor sporulation and poor spore viability (cf. 8 ). Isolation of recessive mutants by mutagenesis of brewers yeast is hampered by the polyploid nature of the strains. While isolation of auxotrophic mutations has been reported from certain brewing yeasts (12), this has not been possible in the Carlsberg lager production strain 244 (9). A previous paper describes the procedure for the isolation of maters from a spo- rulated culture of this strain (3). By crossing two of these meiotic segregants, C80-CG65 and C80CG110, it was possible to construct a hybrid, C80-CG133, which showed a brewing performance equal to the parental strain in pilot scale as well as in production scale $(3,19,20)$. While this result demonstrates the feasibility of crossbreeding of lager yeast, it forms simultaneously the basis for mutation breeding if a desired type of recessive mutation can be induced in the meiotic segregants and subsequently be expressed in a well-performing hybrid. This paper describes the isolation of auxotrophic mutants from meiotic segregants of the lager strain 244.

Breeding through the introduction of a desired

Abbreviations: EMS = ethyl methanesulphonate, $\mathrm{MBC}=$ methyl benzimidazole carbamate, $\mathrm{SC}=$ synthetic complete, $\mathrm{SD}=$ synthetic dextrose, YPD = yeast extract peptone dextrose, YPG = yeast extract peptone glycerol. 
gene by transformation is only possible if the gene is dominant or coupled to another gene which can be positively selected for. Native DNA has been used to transform strains of brewing interest (1) but the general applicability of this method has not been investigated and some mutations could not be transformed in the experiments by JANSEN et al. (7). In addition to the identification of recessive mutants, the present paper describes the transformation of one of the mutants with a plasmid carrying the corresponding wild type gene from $\mathrm{S}$. cerevisiae.

\section{MATERIALS AND METHODS}

\subsection{Strains and media}

The strains used in this study are listed in Tables I and III. The following media were employed: YPD contained 1\% Difco Bacto Yeast Extract, 2\% Difco Bacto Peptone, 2\% glucose. YPG contained 1\% Difco Bacto Yeast Extract, 2\% Difco Bacto Peptone, 3\% glycerol. Synthetic minimal medium, $\mathrm{SD}$, and synthetic complete medium, SC, were prepared according to ZIMMERMANN (22). Medium used for positive selection of lys 2 and lys5 mutants (2) consisted of $2 \%$ glucose, $0.2 \%$ DL- $\alpha$-aminoadipic acid, $0.003 \%$ L-lysine, $0.167 \%$ Bacto Yeast Nitrogen Base without amino acids and ammonium sulfate. Plates were solidified with $2 \%$ Bacto agar. TEbuffer is $10 \mathrm{~mm}$-Tris, ImM-EDTA, pH 8.0.

\subsection{Mutagenesis and isolation of mutants}

Cells were grown in liquid YPD to early stationary phase. UV-mutagenesis was carried out either by plating the cells on YPG and irradiating them in situ or by irradiation of $10^{7}$ cells suspended in $10 \mathrm{ml}$ of water in a Petri dish. Subsequent growth was in the dark. Mutagenesis with EMS (ethyl methanesulfonate) was performed as follows: The cells of $1 \mathrm{ml}$ of culture were washed twice in $\mathrm{H}_{2} \mathrm{O}$ and resuspended in $0.1 \mathrm{M}$-sodium phosphate buffer, pH 7.0. Ten $\mu$ l EMS (Sigma, St. Louis USA) were added and the cells were shaken for 4 hours at $22^{\circ} \mathrm{C}$. The cells were washed twice in $5 \mathrm{ml} 5 \%$ sodium thiosulfate and twice in YPD and resuspended in $1 \mathrm{ml}$ YPD. After shaking at $22^{\circ} \mathrm{C}$ for 24 hours the culture was in some experiments diluted and plated directly on YPD. In other experiments enrichment for auxotrophic mutants was performed by heat kill- ing of exponentially growing cells according to WALTON et al. (18): A stationary phase culture in $\mathrm{SC}$ was washed and diluted hundredfold either in minimal medium or in SC medium lacking histidine and leucine or isoleucine and valine. After eight hours of shaking the culture was exposed to a heat treatment that led to high mortality of growing cells while permitting most stationary phase cells to survive. The conditions had to be optimized for each strain. For instance, C80-CG110 required $48{ }^{\circ} \mathrm{C}$ for five minutes. The treated cells were grown to stationary phase in YPD and subjected to a second cycle of heat killing. Treatment with MBC (methyl benzimidazole carbamate) (21) was carried out as follows: $0.1 \mathrm{ml}$ of a stationary phase culture of mutagenized cells in YPD was transferred to 10 $\mathrm{ml}$ YPD in a flask. After two hours of shaking, a solution of $2 \mathrm{mg} \mathrm{MBC}$ in $0.1 \mathrm{ml}$ dimethyl sulphoxide was added. Following 24 hours of shaking at $22{ }^{\circ} \mathrm{C}$, dilutions were plated on YPD or medium containing $\alpha$-aminoadipic acid. Auxotrophic mutants were found by replica plating of colonies growing on YPD or YPG to plates containing minimal medium (SD) and complete medium (SC). Clones which grew on SC, but failed to grow on $\mathrm{SD}$, were isolated. To test the requirements a loopfull of suspended cells of the isolated clones was streaked on SC lacking individual nutrients.

\subsection{Complementation analysis}

Complementation analysis was attempted by crossing the auxotrophic mutants with the genetically marked strains of S. cerevisiae listed in Table III. A mutation was determined to be allelic to a specific gene in a tester strain when complementation on SD medium failed, while zygote formation and subsequent sporulation could be observed by microscopy.

\subsection{Transformation}

Transformation of intact yeast cells treated with $\mathrm{LiNO}_{3}$ followed the procedure of ITO et al. (6): The cells were shaken in $10 \mathrm{ml}$ YPD until they reached a concentration of about $10^{8}$ cells per $\mathrm{ml}$. The cells were harvested, washed and resuspended in TE-buffer to a density of $2 \times 10^{8}$ cells per $\mathrm{ml}$. Five hundred $\mu \mathrm{l}$ of the cell suspension were mixed with $500 \mu \mathrm{l}$ of $0.2 \mathrm{M}-\mathrm{LiNO}_{3}$ and 
Table I.

Strains derived from spores of strain 244.

\begin{tabular}{|c|c|c|}
\hline Strain & Genotype & Source \\
\hline C80-CG7 & MATa & Meiotic segregant of strain 244 \\
\hline C80-CG65 & MATa & $-n-$ \\
\hline C80-CG121 & $M A T \alpha$ & $-n-$ \\
\hline C80-CG110 & $M A T \alpha$ & $-n=$ \\
\hline C80-CG226 & $M A T \alpha$ &.- \\
\hline C80-CG232 & $M A T \mathbf{a}$ & $\cdots$ \\
\hline C80-CG194 & MAT $\propto$ adel ura 4 & Mutant of C80-CG110 \\
\hline C82-CG679 & leu 2 & $\ldots$ \\
\hline C83-CG756 & leu 2 & Meiotic segregant of C82-CG679×C80-CG65 \\
\hline C83-CG766 & leu2 [LEU2] & Transformant of C83-CG756 \\
\hline
\end{tabular}

Table II.

Mutants isolated from meiotic segregants of the Carlsberg lager yeast strain 244.

\begin{tabular}{|c|c|c|c|c|c|c|c|}
\hline $\begin{array}{l}\text { Strain } \\
\text { mutagenized }\end{array}$ & Mutagen & $\begin{array}{c}\text { Survival } \\
\%\end{array}$ & $\begin{array}{l}\text { Thermal } \\
\text { selection }\end{array}$ & $\begin{array}{l}\text { Colonies } \\
\text { tested }\end{array}$ & $\begin{array}{c}\text { Number of } \\
\text { mutants }\end{array}$ & $\begin{array}{l}\text { Phenotype or } \\
\text { genotype } \\
\text { and chromosome }\end{array}$ & $\begin{array}{c}\text { Mutant } \\
\text { no. }\end{array}$ \\
\hline $\mathrm{C} 80-\mathrm{CG} 7$ & UV & 10 & No & 8000 & $\begin{array}{l}4 \\
1\end{array}$ & $\begin{array}{l}\text { Ura-(leaky) } \\
\text { Arg-(leaky) }\end{array}$ & \\
\hline C80-CG226 & UV & 10 & No & 4000 & 0 & & \\
\hline C80-CG232 & UV & 10 & No & 4000 & 0 & & \\
\hline C80-CG121 & EMS & 70 & No & 4000 & 2 & Met-(leaky) & \\
\hline C80-CG110 & UV & 20 & $\begin{array}{l}\text { Yes (for His-, } \mathrm{Leu}^{-} \text {) } \\
\text { Yes (for Ile-, } \mathrm{Val}^{-} \text {) }\end{array}$ & $\begin{array}{l}4000 \\
4000\end{array}$ & $\begin{array}{l}0 \\
0\end{array}$ & & \\
\hline $\begin{array}{l}\text { C80-CG110 } \\
\text { C80-CG110 }\end{array}$ & $\begin{array}{l}\text { UV } \\
\text { UV }\end{array}$ & $\begin{array}{l}20 \\
20\end{array}$ & $\begin{array}{l}\text { Yes } \\
\text { Yes }\end{array}$ & $\begin{array}{r}200 \\
4000\end{array}$ & $\begin{array}{r}180 \\
1\end{array}$ & $\begin{array}{l}\text { adel urat }(\mathrm{I}, \mathrm{XII}) \\
\text { Aro- }^{-}\end{array}$ & $\begin{array}{l}\text { C80-CG194 } \\
\text { C80-CG208 }\end{array}$ \\
\hline C80-CG110 & EMS & 68 & No & 6000 & 2 & $h i s l(\mathrm{~V})$ & $\begin{array}{l}\text { C80-CG167 } \\
\text { C80-CG168 }\end{array}$ \\
\hline C80-CG110 & EMS & 8 & No & 5000 & $\begin{array}{l}1 \\
1 \\
1 \\
1 \\
2\end{array}$ & $\begin{array}{l}\text { ade2 (XV) } \\
\text { Aro- } \\
\text { leu2 (III) } \\
\text { ura2 (X) } \\
\text { ade6 (VII) }\end{array}$ & $\begin{array}{l}\text { C82-CG604 } \\
\text { C82-CG606 } \\
\text { C82-CG679 } \\
\text { C82-CG680 } \\
\text { C82-CG686 } \\
\text { C82-CG687 }\end{array}$ \\
\hline C80-CG110 & $\begin{array}{l}\text { EMS } \\
(+ \text { MBC } \\
\text { treatment })\end{array}$ & 10 & No & 9000 & $\begin{array}{l}1 \\
1 \\
1 \\
1 \\
1\end{array}$ & $\begin{array}{l}\text { adeb (VII) } \\
\text { His }^{-} \\
\text {Met }^{-} \\
\text {Lys }^{-} \\
\text {lys5 (VII) }\end{array}$ & $\begin{array}{l}\text { C83-CG840 } \\
\text { C83-CG841 } \\
\text { C83-CG845 } \\
\text { C83-CG846 } \\
\text { C83-CG847 }\end{array}$ \\
\hline
\end{tabular}

shaken for 1 hour at $30^{\circ} \mathrm{C}$. One tenth of this suspension was mixed with $10 \mu \mathrm{g}$ (in $10 \mu \mathrm{l} \mathrm{TE}$ buffer) plasmid DNA and $0.1 \mathrm{ml} 70 \%$ polyethylene glycol (Merck no 807490) in water. After incubation for 1 hour at $30^{\circ} \mathrm{C}$ the cells were heated at $42{ }^{\circ} \mathrm{C}$ for $5 \mathrm{~min}$, cooled, washed twice in $\mathrm{H}_{2} \mathrm{O}$ and resuspended in $1.0 \mathrm{ml}$ of water. For selection of leucine prototrophic transformants $0.1 \mathrm{ml}$ of the cell suspension was plated on SCleucine.

\subsection{Colony hybridization}

Molecular hybridization of radioactively labeled plasmid DNA of individual yeast colonies was performed essentially according to HINNEN et al. (5): Colonies were grown on a Millipore HAHY nitrocellulose filter on a YPD plate. Cells were lysed in situ and their DNA was denatured by placing the filter sequentially for the given times on Whatman paper soaked with the following solutions: 50 mм-EDTA, $2.5 \%$ 
Table III.

Complementation analysis of the auxotrophic mutants in meiotic segregants of lager yeast. The genes identified are those which failed to give complementation in crosses with tester strains.

\begin{tabular}{|c|c|c|c|}
\hline $\begin{array}{l}\text { Mutant gene } \\
\text { (identified) }\end{array}$ & & Tester strain & Source \\
\hline \multicolumn{4}{|l|}{ C80-CG194 MAT $\alpha$} \\
\hline \multirow{4}{*}{ adel ura4 } & $\mathrm{C} 80-1308$ & $M A T \mathbf{a}$ ade 2 ilv5 & J.G.L. Petersen \\
\hline & N349-3B & $M A T \mathbf{a}$ ural cdc6 his4 & G. KaWASAKI \\
\hline & $\mathrm{N} 248-1 \mathrm{~A}$ & $\begin{array}{l}\text { MATa adel ura3 gall } \\
\text { his2 trpl met } 14 \text { leul }\end{array}$ & G. KAWASAKI \\
\hline & $3654-5 A$ & $\begin{array}{l}\text { MATa ade6 ura4 his4 trpl } \\
\text { leu2 lys } 2 \text { thr4 tyrl arg4 }\end{array}$ & G. KAWASAKI \\
\hline \multicolumn{4}{|l|}{ C80-CG167 MAT $\alpha$} \\
\hline \multirow{6}{*}{$\begin{array}{l}\text { C80-CG168 MAT } \alpha \\
\text { hisl }\end{array}$} & D286-2A & MATa hisl adel & Cold Spring Harbor Lab. \\
\hline & $\mathrm{N} 248-1 \mathrm{~A}$ & $\begin{array}{l}\text { MATa his2 adel gall leul } \\
\text { ura3 trpl met } 14\end{array}$ & G. KAWASAKl \\
\hline & $\mathrm{X} 5209-11 \mathrm{C}$ & $\begin{array}{l}\text { MATa his } 3 \text { leu2 } 2 \text { lys } 1 \\
\text { ura } 4 \text { met } 10 \text { rad5 } 2\end{array}$ & D. SCHILD \\
\hline & $\begin{array}{l}\text { IV-1 } \\
\text { D609-28C }\end{array}$ & $\begin{array}{l}\text { MATa his4-260 trpl } \\
M A T \text { a his5-2 arg4 lysI } \\
\text { tyr7 trpl }\end{array}$ & $\begin{array}{l}\text { Cold Spring Harbor Lab. } \\
\text { Cold Spring Harbor Lab. }\end{array}$ \\
\hline & $\mathrm{N} 442-4 \mathrm{~A}$ & $\begin{array}{l}\text { MATa his6 ade } 2 \text { lys } 9 \\
\text { trp5 met } 2 \text { arg } 4 \text { ural }\end{array}$ & G. KaWASAKI \\
\hline & $83 \mathrm{~L}$ & $\begin{array}{l}\text { MATa his7 ura3 canl } \\
\text { ade2 hom } 3 \text { spoll cyh2 }\end{array}$ & G. FINK \\
\hline \multicolumn{4}{|l|}{ C82-CG604 MAT $\alpha$} \\
\hline \multirow[t]{2}{*}{ ade2 } & $\mathrm{D} 286-2 \mathrm{~A}$ & MATa adel hisl & Cold Spring Harbor Lab. \\
\hline & $4-\mathrm{I}-20$ & MATa ade2 trp5 ilvI & $\begin{array}{l}\text { T. NiLSSON-TILLGREN } \\
\text { (cont.) }\end{array}$ \\
\hline
\end{tabular}

2-mercaptoethanol, pH 9.0 for $15 \mathrm{~min}, 1 \mathrm{mg}$ per $\mathrm{ml}$ of Zymolyase 6000 in $67 \mathrm{~mm}$-sodium phosphate pH 7.5 for 3.5 hours at $37^{\circ} \mathrm{C} ; 0.1 \mathrm{M}-\mathrm{NaOH}$,

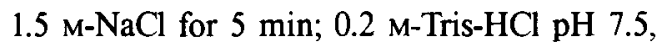
$0.30 \mathrm{M}-\mathrm{NaCl}, 0.03 \mathrm{M}-\mathrm{Na}_{3}$-citrate for two changes, $2 \mathrm{~min}$ each. Preparation of plasmid DNA, ${ }^{32} \mathrm{P}-$ labelling of plasmid DNA by nick translation and hybridization followed standard procedures $(10,16)$.

\section{RESULTS}

\subsection{Isolation and characterization of mutants}

Meiotic segregants of the brewing strain 244 were mutagenized as described in section 2.2 , ei- ther with UV-irradiation or with EMS (ethylmethanesulphonate) treatment. The isolated mutants are listed in Table II. In one experiment EMS treatment of C80-CG110 was followed by treatment with $\mathrm{MBC}$ (methyl benzimidazole carbamate) to induce chromosome loss. Five auxotrophic mutants (ade6, lys5, His', Met', Lys-) were found. The two lysine auxotrophs were isolated on medium containing $\alpha$-aminoadipic acid. In another experiment, six mutants (ade2, leu2, ura2, ade6, Aro-) of the same strain could be isolated without treatment with $\mathrm{MBC}$. Thus MBC treatment did not seem to have a pronounced effect in this case. Thermal selection of auxotrophs had a large effect only in one case: $90 \%$ of the tested colonies were adel ura 4 double 
Table III (contd.)

\begin{tabular}{|c|c|c|c|}
\hline $\begin{array}{l}\text { Mutant gene } \\
\text { (identified) }\end{array}$ & & Tester strain & Source \\
\hline \multicolumn{4}{|l|}{ C82-CG679 } \\
\hline \multirow[t]{2}{*}{ leu2 } & K399-7D & $\begin{array}{l}\text { MATa leuI ura3 his2 lys I } \\
\text { met } 4 \text { pet } 8 \text { spoll }\end{array}$ & S. KLAPHOLZ \\
\hline & $3654-5 \mathrm{~A}$ & $\begin{array}{l}\text { MATa leu2 his4 trpl ura4 } \\
\text { ade6 lys2 thr4 lysl arg4 }\end{array}$ & G. KAWASAKI \\
\hline \multirow[t]{4}{*}{$\begin{array}{l}\text { C82-CG680 MAT } \alpha \\
\text { ura2 }\end{array}$} & A364A & $\begin{array}{l}\text { MATa ural adel ade } 2 \text { gall } \\
\text { lys2 tyrl his } 7\end{array}$ & R. WICNER \\
\hline & 771 & $\begin{array}{l}\text { MATa ura2 arg4 his6 pet } 17 \\
\text { radl met } 4 \text { lys } 5 \text { lys } 7 \text { met } 13 \\
\text { aro2 }\end{array}$ & F. SHERMAN \\
\hline & 192 & MATa ura 3 trpl & G. Stewart \\
\hline & CB-2g-I-II & $\begin{array}{l}\text { MATa ura4 his } 4-29 \text { arg } 4-16 \\
\text { trpl }\end{array}$ & T. NILSSON-TILLGREN \\
\hline 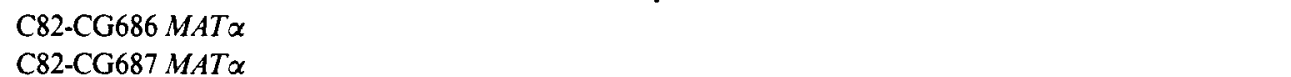 & & & \\
\hline \multirow[t]{3}{*}{ adeb } & $37.72-23 \mathrm{C}$ & $\begin{array}{l}\text { MATa ade } 3 \text { ades leul cyh2 } \\
\text { arg2 ural }\end{array}$ & F. ZIMMERMANN \\
\hline & $3971-5 B$ & $\begin{array}{l}\text { MATa ades, } 7 \text { ilvI gallo } \\
\text { met8 trpl ura3 ura4 leu2 } \\
\text { lys I aro ID canl }\end{array}$ & R. MORTIMMER \\
\hline & MMY 128 & MATa ade6 & M. MCDONELL \\
\hline \multirow[t]{2}{*}{$\begin{array}{l}\text { C83-CG847 MAT } \alpha \\
\text { lys5 }\end{array}$} & 206 & $\begin{array}{l}\text { MATa lys } 2 \text { tyrl his4 trpl } \\
\text { ade6 arg4 gal7 MAL2 }\end{array}$ & G. Stewart \\
\hline & D8-25A & $\begin{array}{l}\text { MATa lys } 5 \text { ade } 5 \text { aro } 2 \text { met } 13 \\
\text { cyh2 trp5 leul ade } 2\end{array}$ & F. ZIMMERMANN \\
\hline
\end{tabular}

mutants. Probably they all descended from the same mutagenized cell. In another experiment only one mutant (Aro-) was found among 4000 colonies. Thermal selection for histidine, leucine, isoleucine and valine auxotrophs did not lead to isolation of mutants. Thus this kind of selection for auxotrophs may be favorable only in special cases. In some of the experiments no mutants could be found. The mutants induced in the strains $\mathrm{C} 80-\mathrm{CG} 7$ and $\mathrm{C} 80-\mathrm{CG} 121$ were leaky, reverted frequently and were not characterized further. Some of the mutants have, as described in section 2.3 , been crossed with genetically marked strains of S. cerevisiae and been found to be allelic to previouly known genes (Table III). Other mutants are being analyzed for assignment to complementation groups.

\subsection{Genetic transformation and characterization of transformants}

Since genetic characterization of the leu $2 \mathrm{mu}$ tant, C82-CG679, is difficult because of its nonmating phenotype, it was crossed to a respiratory deficient derivative of $\mathrm{C} 80-\mathrm{CG} 65$ by rare mating (4) in order to possibly find a segregant with improved mating capacity. Upon sporulation of the hybrid, only four leucine requiring colonies could be found among 6000 tested spore derived clones. Unfortunately, none of these were efficient maters. One of them, C83-CG756, was chosen as a recipient in genetic transformation. The reversion frequency of the mutant is low; no colonies were recovered upon plating $10^{8}$ cells on SC-leucine. Transformation of C83-CG756 was carried out according to ITO et al. (6) with plas- 


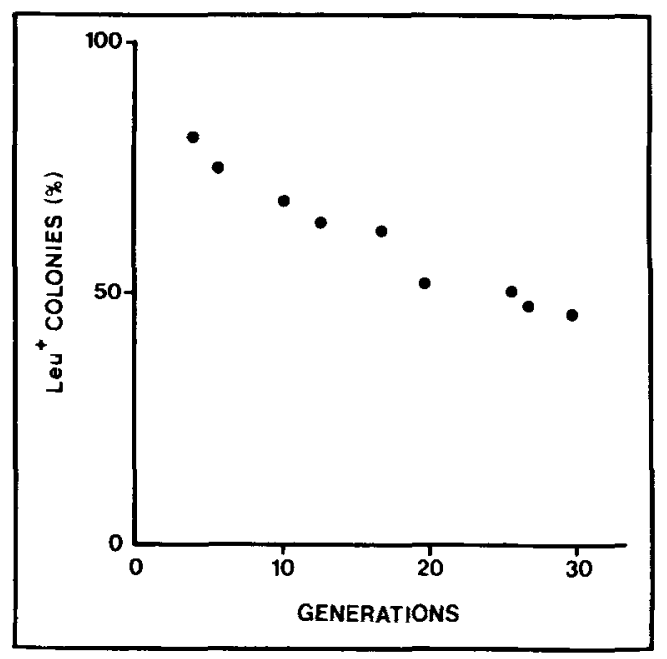

Figure 1. Instability on non-selective medium of the strain C83-CG756 obtained by transforming the leu2 auxotroph C83-CG756 with the plasmid pYF91.2 carrying the $L E U 2$ wild type gene. After 25 cell generations only $50 \%$ of the cells can grow on medium without leucine because of loss of the plasmid.

mid pYF91.2 (17). This plasmid consists of the $L E U 2$ gene from $\mathrm{S}$. cerevisiae, the large EcoRI fragment of the $2 \mu$ yeast plasmid and the bacterial plasmid pBR322 (17). Among $10^{7}$ treated cells plated on medium lacking leucine, four transformants were obtained. For comparison, pYF91.2 was used to transform the $\mathrm{S}$. cerevisiae strain DB746 (MAT $\alpha$ leu2-3 leu2-1l his3 ura3-52 trpl289 ) to leucine prototrophy. Among $0.5 \times 10^{7}$ plated cells, 32 leucine prototrophic colonies were recovered.

The prototrophic transformants of C83CG756 lost the $L E U 2$ carrying plasmid when grown on non-selective medium (Figures 1 and 2). After approximately 25 generations of growth in YPD, $50 \%$ of the cells of transformant C83CG766 had lost the plasmid.

Subclones of C83-CG766 grown on SC-leucine were shown to contain pBR322 sequences by colony hybridization using the procedure described in section 2.4. DNA of all the 34 tested subclones hybridized to radioactively labelled pBR322 DNA, while the DNA from C83-CG756 did not hybridize to the probe (Figure 14 in reference 20).

\section{DISCUSSION}

In the present analysis at least 14 auxotrophic mutants have been isolated in meiotic segregants of a lager brewing strain. Of these nine were found to be allelic to known genes in Saccharomyces cerevisiae located on chromosomes I, III, V, VII, X, XII, and XV. Chromosomes III, $\mathrm{V}$ and XII are known to be homologous or homeologous over all segments analysed in the two species $(13,14,19,20)$. It is likely that this also applies to the other chromosomes. The isolation of mutants in so many linkage groups suggests that with the applied mutagenesis procedures it is possible to select mutations in any gene in appropriate meiotic segregants of lager yeast.

There are three possible explanations for the origin of recessive mutants in the meiotic segregants of the lager yeast. 1) The mutation is induced in a segregant monosomic for the chromosome in question. 2) The mutation is induced in a chromosome for which the strain is disomic and homozygosis results from a subsequent somatic recombination. 3) The mutation is induced in a chromosome for which the strain is disomic but one of the chromosomes in question is lost before or after the mutational event. Strain C80-CG110 is structurally heterozygous and thus disomic for chromosome $\mathrm{V}$ (14). Therefore the first explanation is excluded for the hisl mutation on this chromosome. When the two types of chromosome $\mathrm{V}$ from the lager strain are tested for recombination with the $S$. cerevisiae chromosome in chromosome substitution lines, one is found to recombine normally, the other with only a very low frequency $(14,19,20)$. Since it is likely that the mitotic recombination frequency between the two homeologues is low in $\mathrm{C} 80$ CG110 possibility 3 is the more likely one.

Strain C80-CG110 is structually homozygous or hemizygous for chromosome III $(19,20)$. The leu 2 mutant can have arisen by any of the three possible mechanisms. By studying the chromosome constitution of the mutants it will be possible to decide which modes of origin apply in the individual cases.

A general difficulty in the isolation of mutants has been the slow and non-uniform growth among the mutagenized meiotic segregants. This leads to prolonged incubation time which blurs 


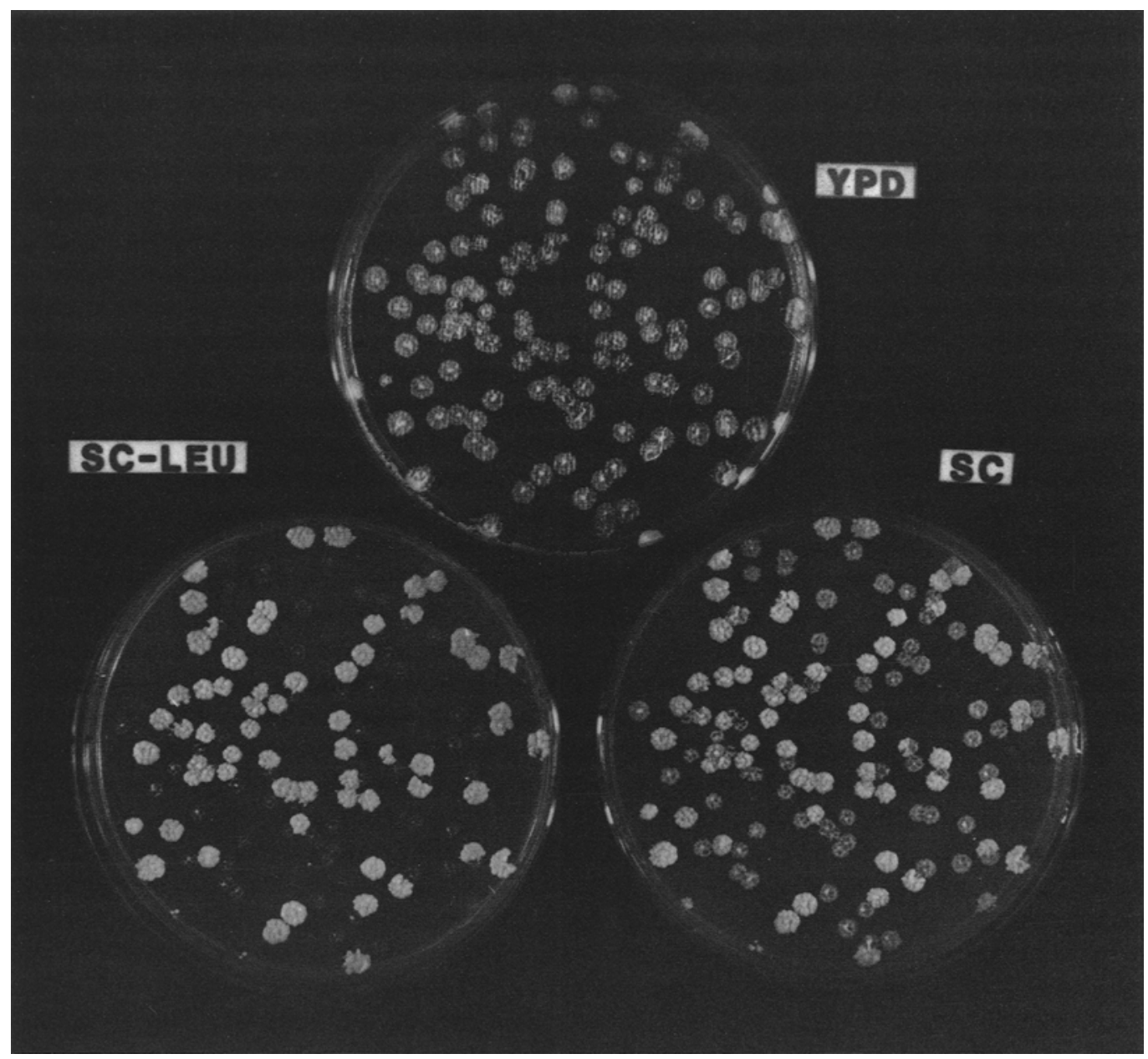

Figure 2. Cells were plated on YPD and the obtained colonies were replica plated onto SC and SC without leucine. The colonies which cannot grow on the plate without leucine have lost the plasmid.

the growth differential between wild type and auxotrophic mutants. This may be the reason that mutagenesis of C80-CG226 and C80. CG232 failed to give any mutants.

Until now the genetic analysis of the Carlsberg lager production strain has been restricted to analysis of single chromosomes in a S. cerevisiae genetic background $(8,13,14)$. The obstacles to conventional genetic analysis have been the low spore viability and the lack of suitable genetic markers. In this paper it is shown that it is possible to isolate mutants of meiotic offspring of the brewing strain. The isolated mutants will be helpful in genetic characterization of single chromosomes (15) as well as in an overall genetic analysis of the lager yeast. In addition, specific mutants may have direct value in breeding. For instance, mutations in the isoleucine-valine biosynthesis can lead to brewing strains producing beer with lower or no diacetyl (11). The finding that mutants of parents of well performing hybrids do not necessarily give rise to successful brewing strains (20) can probably be overcome by suitable cross-breeding programs.

A meiotic segregant, C83-CG656, mutated in the leu2 gene, was transformed to leucine pro- 
totrophy with a chimeric plasmid carrying the wild type $L E U 2$ gene of S. cerevisiae. Transformation of brewing strain derivatives is a necessary prerequisite for introducing genes, which have been modified by site directed mutagenesis. It also opens the possibility to introduce genes which cannot be positively selected for: The vector carrying the $L E U 2$ gene and the leu 2 auxotroph permit to introduce other genes inserted into the vector irrespective of whether the gene can be selected or not.

\section{ACKNOWLEDGEMENTS}

I thank Kirsten Therkildsen and GitTe BANK for technical assistance. The critically reading of the manuscript by MORTEN KIELLAND-BRANDT, and DITER VON WETTSTEIN is gratefully acknowledged. Jens G.L. Petersen, Steen Holmberg, TORsten Nilsson-Tillgren, Julio Polaina and Mogens B. Pedersen are thanked for stimulating discussions.

\section{REFERENCES}

1. Barney, M.C., G.P. Jansen, \& J.R. Helbert: Use of spheroplast fusion and genetic transformation to introduce dextrin utilization into Saccharomyces uvarum. J. Am. Soc. Brew. Chem. $38,1-5(1980)$

2. Chattoo, B.B., F. Sherman, D.A. Azubalis, T.A. Fuellstedt, D. Mehnert, \& M. Ogur: Selection of lys 2 mutants of the yeast Saccharomyces cerevisiae by the utilization of $\alpha$-aminoadipate. Genetics 93, 51-65 (1979)

3. Gjermansen, C., \& P. Sigsgaard: Construction of a hybrid brewing strain of Saccharomyces carlsbergensis by mating of meiotic segregants. Carlsberg Res. Commun. 46, 1-11 (1981)

4. Gunge, N. \& Y. Nakatomi: Genetic mechanisms of rare matings of the yeast Saccharomyces cerevisiae heterozygous for mating type. Genetics 70, 41-58 (1972)

5. Hinnen, A., J.B. Hicks \& G.R. Fink: Transformation of yeast. Proc. Natl. Acad. Sci. USA 75, 1929-1933 (1978)

6. Ito, H., Y. Fukada, K. Murata \& A. Kimura: Transformation of intact yeast cells treated with alkali cations. J. Bacteriol. 153, 163-168 (1983)

7. Jansen, G.P., M.C. Barney, J.R. Helbert \& M.S. Esposito: Nonvector-associated transformation in Saccharomyces. J. Appl. Biochem. 1, 369-376 (1979)

8. Kielland-Brandt, M.C.: The genetics of brewers yeast. Proc. 18th Eur. Brewery Conv. Congr. Copenhagen (1981), 263-276 (1981)

9. Kielland-Brandt, M.C., J.G.L. Petersen \& J.D. MIKKELSEN: Mutants in the biosynthesis of isoleucine in a non-mating, non-sporulating brewing strain of Saccharomyces carlsbergensis. Carlsberg Res. Commun. 44, 27-36 (1979)

10. Livingston, D.M. \& H.L. Klein: Deoxyribonucleic acid sequence organization of a yeast plasmid. J. Bacteriol, 129, 472-481 (1977)

11. Masschelein, C.A., C. Jeunehomme-Ramos, H. Jenard \& A. Devreux: La maturation rapide de la biere - etude des facteurs limitants. Proc. 14th Eur. Brewery Conv. Congr. Estoril 1971, 211-225 (1971)

12. MolzahN, S.W.: A new approach to the application of genetics to brewing yeast. J. Am. Soc. Brew. Chem. 35, 54-59 (1977)

13. Nilsson-Tillgren, T., C. Guermansen, M.C. Kielland-Brandt, J.G.L. Petersen \& S. HolmberG: Genetic differences between Saccharomyces carlsbergensis and $\mathrm{S}$. cerevisjae. Analysis of chromosome III by single chromosome transfer. Carlsberg Res. Commun. 46, 65$76(1981)$

14. Nilsson-Tillgren, T., M.C. KiellandBrandt, S. Holmberg, J.G.L. Petersen \& C. GJERMANSEN: Is lager yeast a species hybrid? Utilization of intrinsic genetic variation in breeding. Proc. IV Symp. Genet Industrial Organisms, 143-147 (1982)

15. Petersen, J.G.L., M.C. Kielland-Brandt, S. Holmberg, T. Nilsson-Tillgren \& C. GJerMANSEN: Homeologous $I L V$ genes in Saccharomyces. Gene Expression in Yeast. Proceedings of the Alko Yeast Symposium Helsinki 1983 , ed. by M. Korhola \& E. Väisänen. Foundation for Biotechnical and Industrial Fermentation Research 1:201-207 (1983)

16. Rigby, P.W.J., M. Dieckmann, C. Rhodes \& P. BERG: Labeling deoxyribonucleic acid to high specific activity in vitro by nick translation with DNA polymerase I. J. Mol. Biol. 113, 237-251 (1977)

17. Storms, R.K., J.B. McNeil, J.B. Khandekar, G. An, J. Parker \& J.D. Friesen: Chimeric plasmids for cloning of deoxyribonucleic acid sequences in Saccharomyces cerevisiae. J. Bacteriol. 140, 73-82 (1979)

18. Walton, E.F., B.L.A. Carter \& J.R. Pringle: An enrichment method for temperature-sensitive and auxotrophic mutants of yeast. Mol. Gen. Genet. 171, 111-114 (1979)

19. Wettstein, D. von: Emil Christian Hansen centennial lecture: From pure culture to genetic 


\section{GJeRMANSEN: Mutagenesis and transformation of lager yeast}

engineering of brewers yeast. Proc. 19th Europ. Brewery Conv. Congr. London 1983, 97-119 (1983)

20. Wettstein, D. von, C. Guermansen, S. Holmberg, M.C. Kielland-Brandt, T. NilsSon-Tillgren, M.B. Pedersen, J.G.L. PeTERSEN \& P. SigsGaARD: Genetic engineering in the improvement of brewers yeast. Master Brew. Assoc. Am. Techn. Quart. 1984, in press
21. WooD, J.: Mitotic chromosome loss induced by methyl-benzimidazole-2-ylcarbamate as a rapid mapping method in Saccharomyces cerevisiae. Mol. Cell. Biol. 2, 1080-1087 (1982)

22. ZiMMERMANN, F.K.: Detection of genetically active chemicals using various yeast systems. In: Chemical mutagens. Principles and Methods for their Detection. A. Hollaender ed., Plenum Press. New York - London, vol. III, 209-239 (1973) 